Nurmala, T. $\cdot$ Ruminta $\cdot$ A. Wahyudin

\title{
Respons pertumbuhan dan hasil tanaman hanjeli batu (Coix lacryma- jobi 1.) akibat pupuk silika cair dan paclobutrazol
}

\author{
Growth and yield of jobs tears (Coix lacryma-jobi 1.) 'batu' due to \\ application of liquid silica fertilizer and paclobutrazol
}

Diterima : 11 Desember 2017/Disetujui : 18 Desember 2017 / Dipublikasikan : 30 Desember 2017

CDepartment of Crop Science, Padjadjaran University

\begin{abstract}
Job'stears "Batu" (Coix lacryma-jobi L.) is one of the alternative food crops that have many prospects. The main problem of this crop is the low yield due to high of vegetative growth during crop cycle life. Thus, this crop need enough in volume and type of nutrition. Silica is one of important nutrition in growth and yields of Job'stears cv. "Batu" and there was no information in application of this nutrition when it was combined with paclobutrazol (PBZ). The objective of this study is to determine the interaction of concentration of liquid silica fertilizer and the concentration of paclobutrazol on growth and yield of Job'stears cv. "Batu". The experiment was conducted at Desa Pasigaran, Kecamatan Tanjungsari, Kabupaten Sumedang from November 2016 to Mei 2017. The experiment design was used in this study was Randomized Block Design (RBD) factorial pattern with 9 treatments and 3 replications. The concentration of liquid silica fertilizer were 20 $\mathrm{ml} / \mathrm{L}, 30 \mathrm{ml} / \mathrm{L}$, and $40 \mathrm{ml} / \mathrm{L}$, while the concentration of PBZ were 1000 ppm, 1500 ppm, and $2000 \mathrm{ppm}$. The results showed that there were no interaction between concentration of treatment of liquid silica fertilizer and paclobutrazol to growth component to yield of Job'stears "Batu".The treatment of 1500 ppm and 2000 ppm PBZ gave single effect to the number of branch, the number of productive tiller, the number of grain and the shoot root ratio on Job'stears cv. "Batu".
\end{abstract}

Keywords : Job's tears "Batu" (Coix lacrymaJobi.L), liquid silica fertilizer, paclobutrazol.

Abstrak. Hanjeli batu (Coix lacryma-jobi L.) merupakan salahsatu tanaman pangan alternatif yang memiliki banyak manfaat. Permasalahan utama tanaman ini adalah rendahnya produksi yang disebabkan oleh kurangnya ketersediaan unsur hara dan tinggi tanaman yang terlalu tinggi. Oleh karena itu dilakukan suatu upaya untuk meningkatkan pertumbuhan dan hasil hanjeli batu dengan pupuk silika cair dan paclobutrazol. Penelitian ini bertujuan untuk mengetahui interaksi konsentrasi pupuk silika cair dan konsentrasi paclobutrazol yang memberikan pengaruh terbaik untuk pertumbuhan dan hasil tanaman hanjeli batu (Coix lacryma-jobi L.). Percobaan dilaksanakan di Desa Pasigaran, Kecamatan Tanjungsari, Kabupaten Sumedang, pada November 2016 sampai Mei 2017. Percobaan menggunakan Rancangan Acak Kelompok (RAK) Faktorial dengan9 perlakuan dan 3 ulangan sebelum aplikasi PBZ, serta9 perlakuan dan 3 ulangan setelah aplikasi PBZ. Diberikan konsentrasi pupuksilika cair sebesar $20 \mathrm{ml} / \mathrm{L}$, $30 \mathrm{ml} / \mathrm{L}$, dan $40 \mathrm{ml} / \mathrm{L}$, sementara konsentrasi paklobutrazol sebesar 1000 ppm, 1500 ppm, dan 2000 ppm. Hasil penelitian menunjukkan bahwa, Tidak terdapat interaksi pemberian konsentrasi perlakuan pupuk silika cair dan paclobutrazol terhadap komponen pertumbuhan dan hasil hanjeli batu. perlakuan paclobutrazol konsentrasi 1500 ppm dan 2000 ppm memberikan pengaruh mandiri terhadap jumlah srisip per rumpun, jumlah malai per rumpun, jumlah biji per rumpun dan nisbah pupus akar pada hanjeli batu.

Kata kunci: Hanjeli (Coix lacryma-Jobi.L), paclobutrazol, pupuk silika cair.

\footnotetext{
Dikomunikasikan oleh Fiky Yulianto Wicaksono

Nurmala, T. ${ }^{1} \cdot$ Ruminta $^{1} \cdot$ A. Wahyudin ${ }^{1}$

1 Staff Pengajar Program Studi Agroteknologi

Korespondensi : tati.nurmala@unpad.ac.id
}

Nurmala, T. $d k k$ : Respons pertumbuhan dan hasil tanaman hanjeli batu (Coix lacryma-jobi 1.) akibat pupuk silika cair dan paclobutrazol 


\section{Pendahuluan}

Diversifikasi pangan dengan potensi pangan lokal merupakan upaya mewujudkan kedaulatan pangan nasional. Menurut Mewa, dkk. (2013) Pelaksanaan penganekaragaman konsumsi pangan menuju konsumsi pangan yang beragam, bergizi, seimbang, dan aman akan memberikan manfaat yang besar, apabila mampu menggali dan mengembangkan potensi sumber-sumber pangan lokal.

Kandungan protein, lemak, dan vitamin B1 pada hanjeli lebih tinggi dibandingkan beras, jagung, milet dan sorgum (Grubben dan Partohardjono, 1996). Kandungan karbohidrat hanjeli juga tidak berbeda jauh dengan kandungan yang ada pada beras dan jagung. Biji hanjeli rata-rata mengandung kadar air 11,04\%; kadar karbohidrat 71,81\%; kadar protein 10,89\%; kadar abu 1,38\%; dan kadar lemak 5,18\% (Nurmala, 2011). Data kandungan biji tersebut menunjukan bahwa hanjeli dapat menjadi salah satu komoditas pangan alternatif.

Hanjeli terbagi ke dalam dua jenis yang sering dibudidayakan yaitu hanjeli pulut dan hanjeli batu. Hanjeli pulut memiliki manfaat sebagai bahan pangan seperti campuran beras, campuran makanan sereal lainnya, bubur hanjeli, dan makanan seperti tape ketan. Hanjeli batu biasanya berumur panjang, senyawa bioaktif beragam, selain untuk pangan juga untuk herbal.

Unsur Si dapat meningkatkan produktivitas tanaman serealia. Pada tanaman padi unsur hara $\mathrm{Si}$ merupakan unsur hara yang diperlukan dalam jumlah besar. Unsur Si ini telah lama diketahui diserap tanaman dalam jumlah besar terutama tanaman akumulator Si. Tanah umumnya mengandung Si cukup banyak sekitar $5-40 \%$ akan tetapi yang tersedia untuk tanaman hanya sedikit dan ketersediaan $\mathrm{Si}$ di dalam tanah lambat laun semakin menipis (Syahfitri, 2016). Tanaman sebagai akumulator $\mathrm{Si}$ adalah famili Gramineae dan Cyperaceae (Ma dan Takahashi, 2002).

Tanaman hanjeli termasuk kedalam suku padi-padian yang merupakan jenis tanaman akumulator Si. Unsur Si dikenal sebagai beneficial element untuk tanaman padi. Kekurangan Si dapat menghambat pertumbuhan tanaman padi. Pemberian unsur $\mathrm{Si}$ dapat menjadikan daun menjadi tidak rentan terhadap penyakit dan hama serta gabah tidak sehat (Epstein, 2009).
Paclobutrazol merupakan zat pengatur tumbuh yang digunakan untuk menghambat pertumbuhan tinggi tanaman. Menurut Penelitian Purwanto dan Inoue (1994) aplikasi paclobutrazol dapat menurunkan biosintesis giberelin yang biasanya terjadi pada suhu rendah.Salah satu peran giberelin yaitu dalam proses pemanjangan sel. Dengan dihambatnya produksi giberelin maka sel terus membelah tapi sel-sel baru tersebut tidak memanjang (Lienargo $d k k$., 2014).

Pemberian zat pengatur tumbuh paclobutrazol ini terhadap tanaman hanjeli bertujuan untuk menghambat pertumbuhan tinggi tanaman dan mempercepat umur panen karena hanjeli merupakan tanaman yang indeterminate. Paclobutrazol dapat menekan pertumbuhan vegetatif sehingga memfokuskan alokasi pati pada pembentukan malai (Aztrina $d k k ., 2014)$.

\section{Bahan dan Metode}

Penelitian ini dilaksanakan di Kecamatan Tanjungsari, Kabupaten Sumedang. Percobaan dilakukan pada bulan November 2016 sampai dengan Juni 2017.

Bahan yang digunakan dalam percobaan ini diantaranya benih hanjeli batu $\mathrm{G}_{37}$ produksi Laboratorium Produksi dan Pemuliaan Tanaman Fakultas Pertanian Unpad, paclobutrazol dengan konsentrasi 1000 ppm, 1500 ppm dan 2000 ppm, dan pupuk silika cair dengan konsentrasi $20 \mathrm{ml} / \mathrm{L}, 30 \mathrm{ml} / \mathrm{L}$ dan $40 \mathrm{~m} / \mathrm{L}$. Pupuk NPK. Untuk pengendalian OPT digunakan pestisida. Alat-alat yang digunakan diantaranya alat tulis, tugal, meteran, cangkul, arit, kored, emrat, ember, karung, timbangan analitik dan alat kekerasan biji penetrometer GY-3.

Rancangan penelitian menggunakan Rancangan Acak Kelompok (RAK) faktorial dengan dua faktor, yaitu terdiri dari pupuk silika cair sebagai faktor pertama dan paclobutrazol sebagai faktor kedua. Faktor pertama terdiri dari 3 taraf konsentrasi:

$\mathrm{s}_{1}=$ Silika Cair $20 \mathrm{ml} / \mathrm{L}$

$\mathrm{s}_{2}=$ Silika Cair $30 \mathrm{ml} / \mathrm{L}$

$\mathrm{s}_{3}=$ Silika Cair $40 \mathrm{ml} / \mathrm{L}$

Faktor kedua yaitu pupuk silika cair dengan 3 taraf konsentrasi:

$\mathrm{p}_{1}=$ Paclobutrazol konsentrasi $1000 \mathrm{ppm}$

$\mathrm{p}_{2}=$ Paclobutrazol konsentrasi $1500 \mathrm{ppm}$

$\mathrm{p}_{3}=$ Paclobutrazol konsentrasi $2000 \mathrm{ppm}$

Masing-masing perlakuan diulang tiga kali sehingga jumlah petak dalam penelitian ini 
sebanyak 27 petak. Penelitian lapangan meliputi kegiatan pengolahan tanah, penyiapan benih, penanaman, pemeliharaan dan pemanenan.

\section{Hasil dan Pembahasan}

Tinggi Tanaman. Pengukuran tinggi tanaman merupakan indikator pertumbuhan yang menunjukkan bahwa pemberian pupuk silika cair memberikan tinggi tanaman yang lebih baik dibandingkan dengan perlakuan tanpa pupuk silika cair. Hal ini sejalan dengan pernyataan Epstein (2009) bahwa silika dapat memperkuat akar dan batang serta mencegah kehilangan transpirasi. Menurut Syahfitri (2016) pemberian pupuk silika secara tidak langsung meningkatkan ketersediaan unsure fosfor di dalam tanah sehingga unsur fosfor tersedia bagi tanaman. Adanya pertambahan tinggi tanaman merupakan bentuk peningkatan sel-sel akibat adanya asimilat yang meningkat.

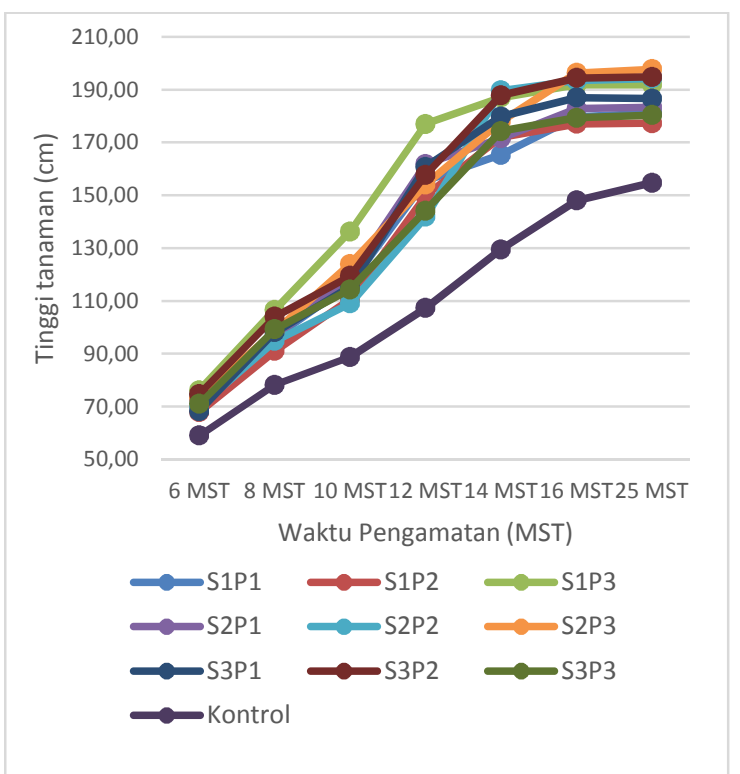

Gambar 1. Kurva Pertumbuhan Tinggi Tanaman Hanjeli Batu.

6 MST : Perlakuan Pupuk Silika Cair 13MST : Perlakuan Paclobutrazol

Berdasarkan kurva pertumbuhan tinggi tanaman hanjeli batu Gambar 1. pada umur 6 minggu setelah tanam (MST) setelah pemberian pupuk silika cair memberikan pengaruh pertumbuhan tinggi yang pesat sampai dengan 13 MST, setelah 13 MST terjadi perubahan pertumbuhan tinggi yang stabil bagi tanaman hanjeli batu. Sejalan dengan pernyataan
Yukamgo (2007) bahwa pemberian pupuk silika dapat memperkuat akar dan batang, meningkatkan respon morfologi tanaman. Pupuk silika berperan dalam proses pembelahan sel serta tahan terhadap cekaman biotik dan abiotik (Epstein,2009).

Pemberian zat pengatur tumbuh paclobutrazol pada 13 MST, mampu menekan pertumbuhan tinggi tanaman sehingga pertumbuhan tinggi relatif sedikit serta stabil setelah 13 MST. Menurut Watson (2006) bahwa paclobutrazol dapat memfokuskan alokasi pati ke malai untuk menghasilkan hasil yang optimal.

Jumlah Daun. Pengamatan jumlah daun hanjeli batu dilakukan pada saat tanaman berumur 6, 8, 10, 12, 14, dan 16 MST.

Berdasarkan kurva pertumbuhan jumlah daun Gambar 2. menunjukkan bahwa pemberian pupuk silika meningkatkan jumlah daun pada fase vegetatif sampai dengan 10 MST. Sejalan menurut Epstein (2009) bahwa silika dapat mencegah gejala daun layu sehingga daun tetap hijau dan terjadi efisiensi fotosintesis. Hasil yang tidak berbeda nyata ini diduga karena hasil analisis tanah awal kandungan Si dalam tanah cukup tinggi yaitu sekitar 43,51 \%, sehingga dapat diduga tidak terdapat pengaruh yang nyata pada tanah yang cukup Si jika diberikan pupuk silika cair.

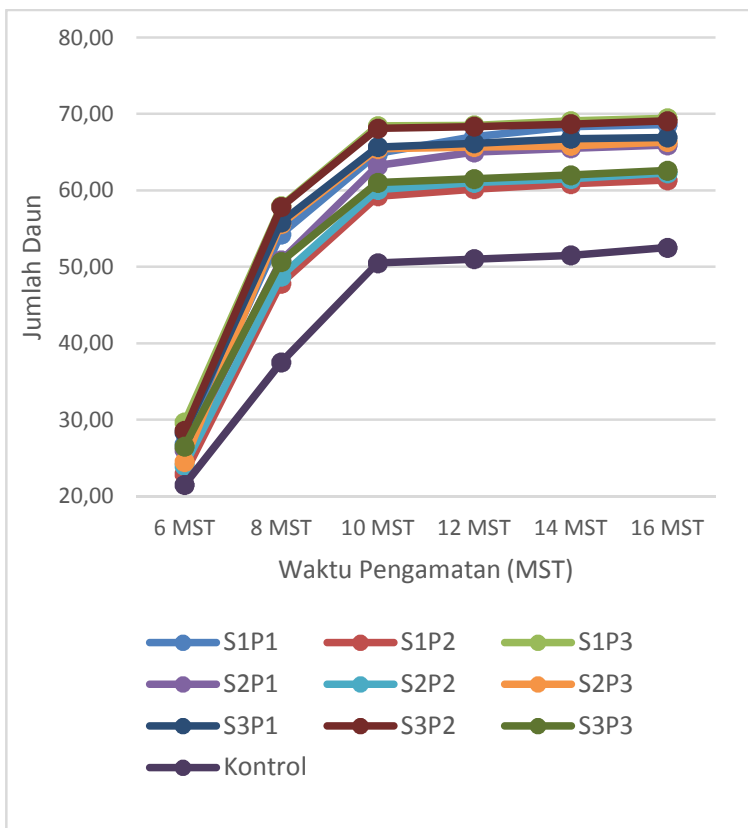

Gambar 2. Kurva Pertumbuhan Jumlah Daun Tanaman Hanjeli Batu.

6 MST : Perlakuan Pupuk Silika Cair

13 MST : Perlakuan Paclobutrazol 
Hasil menunjukkan bahwa pemberian pupuk silika cair memberikan jumlah daun yang lebih baik dibandingkan dengan perlakuan tanpa pupuk silika cair. Menurut Syahfitri (2016) pemberian pupuk silika secara tidak langsung meningkatkan ketersediaan $\mathrm{P}$ didalam tanah sehingga $P$ tersedia bagi tanaman.

Perlakuan paklobutrazol tidak memberikan pengaruh yang berbeda nyata terhadap jumlah daun tanaman hanjeli batu. Paklobutrazol mengakibatkan laju penambahan luas daun rendah bahkan tetap. Faktor lain yang menyebabkan tidak berpengaruh nyata diduga karena ketersediaan unsur hara di dalam tanah mencukupi untuk pertumbuhan tanaman hanjeli batu. Unsur nitrogen membantu pembentukan vegetatif tanaman, seperti daun, batang dan akar.

Jumlah Anakan per Rumpun. Pengamatan jumlah anakan hanjeli batu dilakukan pada saat tanaman berumur 6, 8, 10, 12, 14, dan 16 MST.

Berdasarkan kurva pertumbuhan jumlah anakan tanaman hanjeli batu Gambar 3. menghasilkan jumlah anakan berkisar 11-13 anakan pada umur 16 MST. Pemberian paclobutrazol membuat pertumbuhan jumlah anakan cenderung stabil. Meskipun tidak berbeda nyata, namun pemberian berbagai perlakuan dosis pupuk silika cair dan konsentrasi pacloburazol menghasilkan jumlah anakan yang lebih baik dibandingkan dengan perlakuan kontrol.

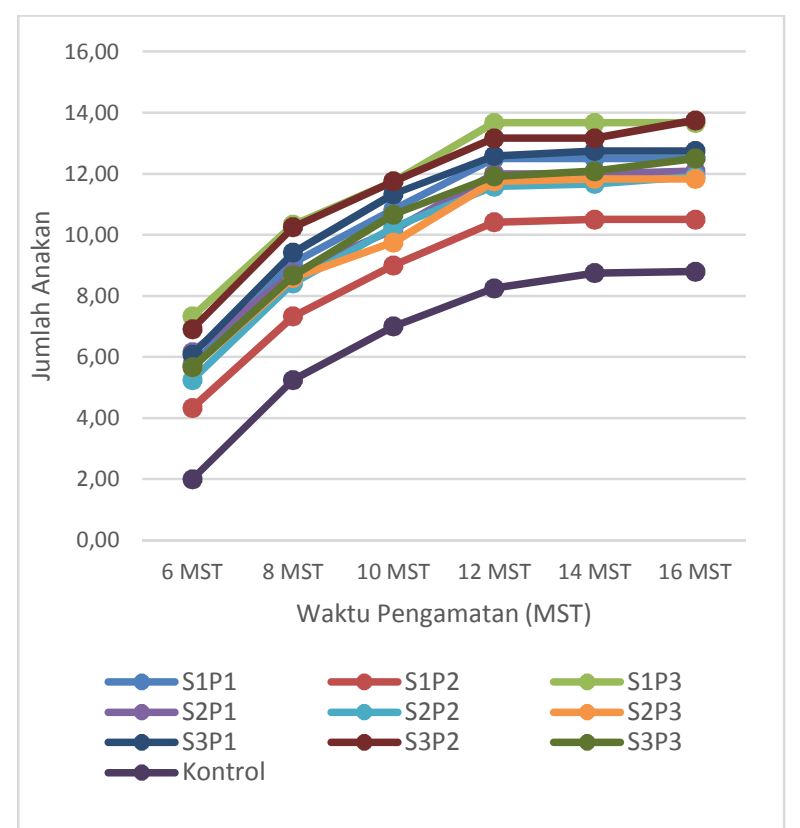

Gambar 3. Kurva Pertumbuhan Jumlah Anakan Tanaman Hanjeli Batu.

6 MST : Perlakuan Pupuk Silika Cair

13MST : Perlakuan Paclobutrazol
Indeks Luas Daun. Pengukuran indeks luas daun hanjeli batu dilakukan pada saat tanaman berumur 12 MST. Indeks luas daun merupakan parameter yang menunjukan potensi tanaman melakukan fotosintesis dan juga potensi produktif tanaman di lapangan.

Berdasarkan hasil analisis data statistik pada Tabel 1. bahwa tidak terdapat interaksi antara perlakuan konsentrasi pupuk silika cair dan paclobutrazol terhadap indeks luas daun tanaman hanjeli batu.

Perlakuan konsentrasi pupuk silika cair dan paclobutrazol menunjukkan hasil yang tidak berbeda nyata terhadap indeks luas daun.

Hal ini diduga karena kerapatan tanaman. Jarak tanam yang sempit pada akhir fase vegetatif, mengakibatkan sedikitnya radiasi cahaya yang sampai ke lapisan daun bagian bawah hingga ke tanah.

Jumlah Srisip Per Rumpun. Srisip adalah malai lateral atau kumpulan dari malai utama. Srisip muncul dari ketiak daun. Berdasarkan hasil analisis data statistik pada Tabel 1. bahwa tidak terdapat interaksi antara perlakuan konsentrasi pupuk silika cair dan paclobutrazol terhadap jumlah srisip per rumpun tanaman hanjeli batu pada saat menjelang panen. Secara mandiri perlakuan berbagai konsentrasi pupuk silika cair menunjukan hasil yang tidak berbeda nyata. Hal ini diduga bahwa jumlah srisip tidak dipengaruhi oleh unsur hara $\mathrm{Si}$, melainkan faktor genetik dari tanaman itu sendiri (Yelis, 2011).

Faktor lain diduga karena hasil analisis tanah awal kandungan Si dalam tanah cukup tinggi yaitu sekitar 43,51 \%, sehingga dapat diduga tidak terdapat pengaruh yang nyata pada tanah yang cukup Si jika diberikan pupuk silika cair. Perlakuan konsentrasi paclobutrazol yang berbeda memberikan pengaruh mandiri yang berbeda nyata terhadap jumlah srisip dengan respon terbaik ditunjukkan pada perlakuan $\left(\mathrm{p}_{2}\right) 1500 \mathrm{ppm}$. Konsentrasi paclobutrazol 1500 ppm berbeda nyata dengan 2000 ppm tetapi tidak berbeda nyata dengan $1000 \mathrm{ppm}$.

Hal ini diduga karena paclobutrazol yang diaplikasikan dapat langsung diserap oleh tanaman melalui stomata dan mampu mengarahkan suplai fotosintat ke srisip yang dihasilkan dari proses fotosintesis di daun. Sejalan dengan pernyataan Watson (2006) fotosintat yang semula digunakan untuk pertumbuhan vegetatif nantinya akan dialokasikan untuk pertumbuhan generatif. Paclobutrazol 
diabsorpsi oleh tanaman melalui daun, akar atau pembuluh batang yang kemudian ditranslokasikan oleh xilem ke bagian tanaman lain sehingga pengaplikasiannya dapat dilakukan dengan cara disemprotkan ke daun (foliar spray) atau disiramkan ke tanah (soildrench).

Tabel 1. Pengaruh Mandiri Konsentrasi Pupuk Silika Cair dan Konsentrasi Paclobutrazol terhadap Jumlah Srisip, Jumlah Malai, dan Jumlah Biji Per Rumpun Hanjeli Batu.

\begin{tabular}{|c|c|c|c|c|}
\hline Perlakuan & ILD & $\begin{array}{l}\text { Jumlah } \\
\text { Srisip Per } \\
\text { Rumpun }\end{array}$ & $\begin{array}{l}\text { Jumlah } \\
\text { Malai Per } \\
\text { Rumpun }\end{array}$ & $\begin{array}{l}\text { Jumlah Biji } \\
\text { Per } \\
\text { Rumpun }\end{array}$ \\
\hline $\begin{array}{c}\text { Pupuk Silika } \\
\text { Cair }\end{array}$ & & & & \\
\hline $\begin{array}{l}20 \mathrm{ml} / \mathrm{L}\left(\mathrm{s}_{1}\right) \\
30 \mathrm{ml} / \mathrm{L}\left(\mathrm{s}_{2}\right) \\
40 \mathrm{ml} / \mathrm{L}\left(\mathrm{s}_{3}\right)\end{array}$ & $\begin{array}{l}3,87 \mathrm{a} \\
3,62 \mathrm{a} \\
3,79 \mathrm{a}\end{array}$ & $\begin{array}{l}66,53 \text { a } \\
68,81 \text { a } \\
66,94 \text { a }\end{array}$ & $\begin{array}{l}532,22 \mathrm{a} \\
550,44 \mathrm{a} \\
535,56 \mathrm{a}\end{array}$ & $\begin{array}{l}1663,19 \mathrm{a} \\
1703,47 \mathrm{a} \\
1672,50 \mathrm{a}\end{array}$ \\
\hline Paclobutrazol & & & & \\
\hline $\begin{array}{l}1000 \operatorname{ppm}\left(\mathrm{p}_{1}\right) \\
1500 \mathrm{ppm}\left(\mathrm{p}_{2}\right) \\
2000 \mathrm{ppm}\left(\mathrm{p}_{3}\right)\end{array}$ & $\begin{array}{l}3,69 \mathrm{a} \\
3,53 \mathrm{a} \\
4,06 \mathrm{a}\end{array}$ & $\begin{array}{l}69,00 \mathrm{ab} \\
76,94 \mathrm{~b} \\
56,33 \mathrm{a}\end{array}$ & $\begin{array}{c}552,00 \mathrm{ab} \\
615,56 \mathrm{~b} \\
450,67 \mathrm{a}\end{array}$ & $\begin{array}{l}1718,33 \mathrm{ab} \\
1912,50 \mathrm{~b} \\
1408,33 \mathrm{a}\end{array}$ \\
\hline Kontrol & 3,16 & 38,75 & 310,00 & 968,75 \\
\hline
\end{tabular}

Keterangan : Nilai rata-rata yang diikuti oleh huruf yang sama tidak berbeda nyata menurut Uji Jarak Berganda Duncan pada taraf $5 \%$.

Jumlah Malai Per Rumpun. Tidak terjadi interaksi antara pupuk Silica dan Paclobutrazol. Pemberian perlakuan konsentrasi pupuk silika cair dan paclobutrazol menghasilkan jumlah malai per rumpun yang lebih baik dibandingkan dengan perlakuan kontrol. Kekurangan atau tidak adanya pemberian Si pada tanaman padi dapat mengakibatkan meningkatnya jumlah malai dan panjang malai yang dihasilkan (Ma dan Takahashi, 2002). Silika secara tidak langsung meningkatkan ketersediaan P dalam tanah, silika juga dapat meningkatkan translokasi $\mathrm{P}$ ke malai, sehingga peran $\mathrm{P}$ lebih optimal bagi tanaman (Balittanah, 2011).

Perlakuan konsentrasi paclobutrazol yang berbeda memberikan pengaruh mandiri yang berbeda nyata terhadap jumlah malai dengan respon terbaik ditunjukkan pada perlakuan $\left(\mathrm{p}_{2}\right)$ 1500 ppm. Konsentrasi paclobutrazol 1500 ppm berbeda nyata dengan 2000 ppm tetapi tidak berbeda nyata dengan 1000 ppm. Hal ini diduga karena paclobutrazolyang diaplikasikan dapat langsung diserap oleh tanaman melalui stomata dan mampu mengarahkan suplai fotosintat ke malai yang dihasilkan dari proses fotosintesis di daun. Sejalan dengan pernyataan Watson (2006) fotosintat yang semula digunakan untuk pertumbuhan vegetatif nantinya akan dialokasikan untuk pertumbuhan generatif.

Jumlah Biji Per Rumpun. Tabel 1 menunjukkan tidak terdapat interaksi antara perlakuan konsentrasi pupuk silika cair dan paclobutrazol terhadap jumlah biji per rumpun tanaman hanjeli batu.

Pengaruh mandiri perlakuan berbagai konsentrasi pupuk silika cair menunjukkan hasil yang tidak berbeda nyata terhadap jumlah biji per rumpun tanaman hanjeli batu. Hal ini diduga karena hasil analisis tanah awal kandungan Si dalam tanah cukup tinggi yaitu sekitar 43,51 \%, sehingga dapat diduga tidak terdapat pengaruh yang nyata pada tanah yang cukup Si jika diberikan pupuk silika cair. Jumlah biji berbanding lurus dengan jumlah malai yang diamati. Semakin besar jumlah malai, maka jumlah bijinya akan semakin besar. Hal ini dikarenakan bakal biji tumbuh disetiap malai. Biji hanjeli dapat terbentuk optimal apabila faktor pertumbuhannya terjaga, seperti unsur hara, pengelolaan air, dan pemupukan (Yusuf, 2016).

Perlakuan konsentrasi paclobutrazol yang berbeda memberikan pengaruh mandiri yang berbeda nyata terhadap jumlah biji dengan respon terbaik ditunjukkan pada perlakuan $\left(\mathrm{p}_{2}\right)$ 1500 ppm. Konsentrasi paclobutrazol 1500 ppm berbeda nyata dengan 2000 ppm tetapi tidak berbeda nyata dengan 1000 ppm. Hal ini diduga karena paclobutrazolyang diaplikasikan dapat langsung diserap oleh tanaman melalui stomata dan mampu mengarahkan suplai fotosintat ke malai yang dihasilkan dari proses fotosintesis di daun. Sehingga malai menghasilkan biji yang baik. Sejalan dengan pernyataan Watson (2006) fotosintat yang semula digunakan untuk pertumbuhan vegetatif nantinya akan dialokasikan untuk pertumbuhan generatif.

Bobot Biji Per Rumpun. Berdasarkan hasil analisis data statistik pada Tabel 2. bahwa tidak terdapat interaksi antara perlakuan konsentrasi pupuk silika cair dan paclobutrazol terhadap bobot biji per rumpun. Pada Tabel 3. Menunjukkan pengaruh mandiri bahwa perlakuan berbagai dosis pupuk silika cair dan konsentrasi paclobutrazol menunjukkan hasil yang tidak berbeda nyata.

Pemberian pupuk silika cair dan paclobutrazol menghasilkan bobot biji yang lebih baik dibandingkan dengan perlakuan kontrol. Menurut Sitompul dan Guritno (1995) dalam Yelis R. D. (2011) unsur P merupakan 
bahan untuk pembentukan protein dalam biji, sedangkan unsur $\mathrm{K}$ berperan dalam bertambahnya bobot biji. Bobot biji per rumpun pada percobaan ini berkisar 263,23-303,21 g dan menurut Antonius (2016) bobot biji per rumpun hanjeli batu berkisar 270,10-292,92 g.

Tabel 2. Pengaruh Mandiri Konsentrasi Pupuk Silika Cair dan Paclobutrazol terhadap Bobot Biji Per Rumpun,Bobot Biji Per Hektar, Dan Bobot 100 Biji Hanjeli Batu.

\begin{tabular}{ccl}
\hline Perlakuan & $\begin{array}{c}\text { Bobot Biji Per } \\
\text { Rumpun }(\mathrm{g})\end{array}$ & Bobot 100 Biji (g) \\
\hline Pupuk Silika Cair & & \\
$20 \mathrm{ml} / \mathrm{L}\left(\mathrm{s}_{1}\right)$ & $275,75 \mathrm{a}$ & $16,33 \mathrm{a}$ \\
$30 \mathrm{ml} / \mathrm{L}\left(\mathrm{s}_{2}\right)$ & $263,23 \mathrm{a}$ & $15,42 \mathrm{a}$ \\
$40 \mathrm{ml} / \mathrm{L}\left(\mathrm{s}_{3}\right)$ & $280,07 \mathrm{a}$ & $16,53 \mathrm{a}$ \\
\hline Paclobutrazol & & \\
$1000 \mathrm{ppm}\left(\mathrm{p}_{1}\right)$ & $291,94 \mathrm{a}$ & $16,56 \mathrm{a}$ \\
$1500 \mathrm{ppm}\left(\mathrm{p}_{2}\right)$ & $303,51 \mathrm{a}$ & $15,81 \mathrm{a}$ \\
2000 ppm $\left(\mathrm{p}_{3}\right)$ & $223,59 \mathrm{a}$ & $15,92 \mathrm{a}$ \\
\hline Kontrol & 113,83 & 11,75 \\
\hline
\end{tabular}

Keterangan : Nilai rata-rata yang diikuti oleh huruf yang sama tidak berbeda nyata menurut Uji Jarak Berganda Duncan pada taraf $5 \%$.

Bobot 100 Biji. Berdasarkan hasil analisis data statistik pada Tabel 2. bahwa tidak terdapat interaksi antara perlakuan konsentrasi pupuk silika cair dan paclobutrazol terhadap bobot 100 biji tanaman hanjeli batu. Pengaruh mandiri perlakuan berbagai konsentrasi pupuk silika cair dan paclobutrazol menunjukkan hasil yang tidak berbeda nyata terhadap bobot 100 biji tanaman hanjeli batu.

Bobot 100 biji hasil percobaan memiliki rata -rata hasil sebesar 15 - $16 \mathrm{~g}$, sejalan menurut Antonius (2016) bahawa bobot 100 biji per rumpun hanjeli batu berkisar antara 15-17 g. pemberian pupuk silika cair dan paclobutrazol menghasilkan bobot 100 biji yang lebih baik dibandingkan dengan perlakuan kontrol. Faktor lain diduga karena perlakuan paclobutrazol yang masih harus ditingkatkan dalam interval waktu pengaplikasiannya, faktor genetik dan juga penanaman pada kondisi lingkungan yang optimal.

Rendemen Biji Pecah Kulit (RBPK). Pada Tabel 3. menunjukkan pengaruh mandiri bahwa perlakuan berbagai konsentrasi pupuk silika cair dan paclobutrazol menunjukkan hasil yang tidak berbeda nyata terhadap rendemen biji pecah kulit tanaman hanjeli batu. Pemberian perlakuan pupuk silika cair dan paclobutrazol mendapatkan hasil yang lebih baik dibandingkan dengan perlakuan kontrol. Inisiasi biji menjadi daerah pemanfaatan yang dominan untuk tanaman semusim, oleh sebab itu selama pengisian biji sebagian besar hasil asimilasi yang terbentuk maupun yang tersimpan digunakan untuk meningkatkan berat biji (Gardner $d k k$, 1991).

Tabel 3. Pengaruh Mandiri Konsentrasi Pupuk Silika Cair dan Paclobutrazol terhadap Rendemen Biji Pecah Kulit, Indeks Panen, Dan Kekerasan Biji Hanjeli Batu

\begin{tabular}{cccc}
\hline Perlakuan & IP & *RBPK & $\begin{array}{c}\text { Kekerasan } \\
\text { Biji (lbf) }\end{array}$ \\
\hline Pupuk Silika Cair & & & \\
$20 \mathrm{ml} / \mathrm{L}$ & $0,35 \mathrm{a}$ & $57,66 \mathrm{a}$ & $27,04 \mathrm{a}$ \\
$30 \mathrm{ml} / \mathrm{L}$ & $0,30 \mathrm{a}$ & $56,28 \mathrm{a}$ & $26,33 \mathrm{a}$ \\
$40 \mathrm{ml} / \mathrm{L}$ & $0,31 \mathrm{a}$ & $59,14 \mathrm{a}$ & $27,79 \mathrm{a}$ \\
\hline Paclobutrazol & & & \\
$1000 \mathrm{ppm}$ & $0,33 \mathrm{a}$ & $55,43 \mathrm{a}$ & $26,44 \mathrm{a}$ \\
$1500 \mathrm{ppm}$ & $0,34 \mathrm{a}$ & $59,55 \mathrm{a}$ & $27,56 \mathrm{a}$ \\
$2000 \mathrm{ppm}$ & $0,28 \mathrm{a}$ & $58,09 \mathrm{a}$ & $27,17 \mathrm{a}$ \\
Kontrol & 0,21 & 38,60 & 20,60 \\
\hline
\end{tabular}

*RBPK: Rendemen Biji Pecah Kulit, *IP: Indeks Panen Keterangan : Nilai rata-rata yang diikuti oleh huruf yang sama tidak berbeda nyata menurut Uji Jarak Berganda Duncan pada taraf 5\%.

Kekerasan Biji. Tidak terdapat interaksi antara perlakuan konsentrasi pupuk silika cair dan paclobutrazol terhadap kekerasan biji tanaman hanjeli batu. Perlakuan pupuk silika cair dan paclobutrazol memberikan hasil kekerasan biji yang lebih baik dibandingkan dengan perlakuan kontrol yaitu rata-rata 26,5 lbf. Menurut (Syahfitri, 2016) hanjeli pulut memiliki kekerasan biji dengan rata-rata $22 \mathrm{lbf}$, dan menurut Antonius (2016) hanjeli batu memiliki kekerasan biji dengan rata-rata 24,5 lbf

Hal ini diduga karena pemberian pupuk silika cair membuat kulit biji hanjeli batu cenderung menjadi lebih keras dibandingkan dengan perlakuan kontrol. Selain itu, Jenis hanjeli batu memiliki kekerasan biji lebih besar dibanding dengan hanjeli jenis pulut dikarenakan faktor genetik juga mempengaruhi kekerasan biji (Yusuf, 2016). Menurut Nurmala (1998) menyatakan bahwa jenis hanjeli pulut memiliki kulit biji yang lebih tipis dari hanjeli batu, sehingga lebih mudah diolah menjadi makanan. Biji hanjeli batu memiliki kulit yang lebih keras dibanding dengan hanjeli pulut.

Indeks Panen. Indeks panen merupakan perbandingan bobot biji dibagi dengan bobot 
biomassa tanaman.Berdasarkan hasil analisis data statistik pada Tabel 3. bahwa tidak terdapat interaksi antara perlakuan konsentrasi pupuk silika cair dan paclobutrazol terhadap indeks panen tanaman hanjeli batu.

Meskipun tidak berbeda nyata, pemberian pupuk silika cair dan paclobutrazol memberikan hasil yang lebih baik dibandingkan dengan perlakuan kontrol. Menurut Syahfitri (2016) indeks panen menggambarkan proporsi fotosintat yang ditranslokasikan kedalam bagian penyimpanan cadangan makanan. Fotosintat yang dihasilkan daun ditranslokasikan ke dalam bagian cadangan dalam bentuk biji.

\section{Kesimpulan}

Kesimpulan dari percobaan ini adalah :

1. Tidak terdapat interaksi antara konsentrasi pupuk silika cair dengan paclobutrazol terhadap komponen pertumbuhan dan hasil hanjeli batu.

2. Konsentrasi pupuk silika cair tidak memberikan pengaruh yang bebrbeda nyata terhadap komponen pertumbuhan dan komponen hasil hanjeli batu. Konsentrasi paclobutrazol pada 1500 ppm memberikan pertumbuhan dan hasil dengan respon terbaik pada jumlah srisip per rumpun yang mencapai 76,94 , jumlah malai per rumpun 615,56 dan jumlah biji per rumpun 1912,50. Konsentrasi 2000 ppm memberikan respon terbaik pada nisbah pupus akar 2,79.

Saran. Pemberian Paclobutrazol sebaiknya ditingkat-kan dengan pemberian pada fase pengisian biji pada 7 MST.

\section{Ucapan Terimakasih}

Ucapan terimakasih disampaikan kepada Mohamad Satya, S.P. alumni Program Studi Agroteknologi Fakultas Pertanian Universitas Padjadjaran yang telah membantu penulis di lapangan melalui projek ALG.

\section{Daftar Pustaka}

Antonius Y. 2016. Respons Pertumbuhan dan Hasil Tanaman Hanjeli (Coix lacryma-jobi L) Terhadap Kombinasi Jarak Tanam dan
Jenis Pupuk Kandang di Dataran Medium Sukasari Sumedang. Skripsi Fakultas Pertanian Universitas Padjadjaran.

Aztrina A., Kardhinata E. 2014. Pengaruh Paclobutrazol Terhadap Jumlah Klorofil, Umur Berbunga, Umur Panen Dua Varietas Sorgum (Sorghum bicolor (L.) Moench). Medan: Jurnal Online Agroekoteknologi. ISSN No. 2337-6597 Vol 2, No 4 : 1296-1299.

Balittanah. 2011. Warta Penelitian dan Pengembangan Pertanian. Vol 33 no. 3. Balittanah, Bogor. 12-13

Epstein, E. 2009. Silicon: its manifold roles in plants. Annals of Applied Biology Vol. 155: 155-160 ISSN 0003-4746.

Gardner, F. P.; R. B. Pearce dan R. L. Mitchell. 1991 Fisiologi Tanaman Budidaya. Terjemahan: Herawati Susilo. UI Press, Jakarta.

Grubben G.J.H dan Partohardjono S. (eds) 1996. Plant Resources of South-East Asia no 10 Cereals.Porsea.Bogor.

Lienargo Rizky B, Semuel, Johannes, Tumewu. 2014. Pengaruh Waktu Penyemprotan dan Konsentrasi Paclobutrazol (PBZ) terhadap pertumbuhan dan produksi tanaman jagung varietas Manado Kuning. Manado: J. Universitas Sam Ratulangi Vol 4 No 1.

Ma , J . F. and E. Takahashi. 2002. Soil, Fertilizer, and Plant Silicon Research in Japan. Elsevier, Amsterdam.

Nurmala, Tati dan Aep W. Irwan. 2007. Pangan Alternatif: Berbasis Serealia Minor. Bandung: Pustaka Giratuna.

Nurmala, Tati. 2011. Potensi dan Prospek Pengembangan Hanjeli (Coix lacryma-jobi L.) sebagai Pangan Bergizi Kaya Lemak Untuk Mendukung Diversifikasi Pangan Menuju Ketahanan Pangan Mandiri. Pangan: Media Komunikasi dan Informasi Vol. 20 (1): 1-103.

Nurmala, T., Yuniarti A., Syahfitri N. 2016. Pengaruh berbagai dosis pupuk silika organik dan tingkat kekerasan biji terhadap pertumbuhan dan hasil tanaman hanjeli pulut (Coix lacryama jobi L) genotip 37: Jurnal Kultivasi Vol. 15 (2)

Poerwanto, R. Dan H. Inoue. 1994. Pengaruh paclobutrazol terhadap pertumbuhan dan pembungaan jeruk Satsuma mandarin pada beberapa kondisi suhu. Bul.Agron. 22: 55-67.

Rahmawati Dian Eka. 2003. Estimasi Heritabilitas dengan Metode Regresi Tetuaturunan (Parents - offspring regression) 
dan Kemajuan Genetik Beberapa Karakter Penting Hanjeli (Coix lacryama-jobi L.) di Arjasari. Fak. Pertanian Univ. Padjadjaran.

Sitompul, S.M dan B. Guritno. 1995. Analisis Pertumbuhan Tanaman. Universitas Gadjah Mada. Yogyakarta.

USDA, 2014. Coix lacryma-jobi L-Job`s Tear. Plants Database United States Department of Agriculture. Tersedia online di: http://plants.usda.gov/java/reference?sy mbol=COLA Diakses 21 November 2016

Watson W. 2006. The Effect of Paclobutrazol Treatment on Starch Content, Mychorizal
Colonization, and Fine Root Density of White Oaks (Querus alba L.). Arboriculture and Urban Forestry 32(3)

Yelis, R. 2011. Peningkatan Produktivitas Hanjeli Indigenous Kiara Payung Sebagai Pangan Bergizi dengan Pemberian Pupuk N, P, K pada Dosis dan Waktu yang Berbeda. Budidaya Pertanian. Fakultas Pertanian Universitas Padjadjaran.

Yukamgo, E, dan N. W. Yuwono. 2007. Peran Silikon Sebagai Unsur Bermanfaat Pada Tanaman Tebu. Jurnal Ilmu Tanah dan Lingkungan Vol. 7 : 2 (103-116) (2007). 